\title{
A Study on the Influence of Career Growth on Work Engagement among New Generation Employees
}

\author{
Jing Bai, Jinping Liu \\ School of Business Administration, South China University of Technology, Guangzhou, China \\ Email: 851716764@qq.com
}

How to cite this paper: Bai, J. and Liu, J.P. (2018) A Study on the Influence of Career Growth on Work Engagement among New Generation Employees. Open Journal of Business and Management, 6, 300-317. https://doi.org/10.4236/ojbm.2018.62022

Received: March 12, 2018

Accepted: April 17, 2018

Published: April 20, 2018

Copyright $\odot 2018$ by authors and Scientific Research Publishing Inc. This work is licensed under the Creative Commons Attribution International License (CC BY 4.0).

http://creativecommons.org/licenses/by/4.0/

\begin{abstract}
Based on the questionnaire of 207 enterprise employees in South China, this paper uses the method such as hierarchical regression analysis, to explore the relationship between career growth and work engagement, the intermediary role of organizational identification and the moderating effect of person-organization value fit. The study shows that: 1) Employee career growth has a significant positive impact on organizational identification and work engagement; 2) Organizational identification plays a partial mediating role between career growth and work engagement; 3) Person-organization value fit positively regulates the relationship between career growth and organizational identification. That is to say, the higher the person-organization value fit, the more obvious the influence of career growth on organizational identification. Finally, based on the results, the paper discusses the significance of this research in theory and practice.
\end{abstract}

\section{Keywords}

Career Growth, Work Engagement, Organizational Identification, Person-Organization Value Fit

\section{Introduction}

In the era which information technology rapidly develops, the pace of economic development in China is accelerating and the development trend of the business organization towards the flat is becoming more and more obvious. This made the relationship between person and organization fundamentally changed. At the same time, to survive and gain a competitive superiority in the wave of glob- 
al economic development, enterprises need to create talent superiority and place enhancing employees' input and output in a priority position.

However, according to the employee engagement Survey which Gallup released in November 2013, only 13\% of employees in the world are engaged in their work and $87 \%$ of employees are not engaged in their work or efficient. While Only $6 \%$ of employees in China are engaged in the job, far below the global average [1]. The report released by Steelcase and well-known research company IPSOS in March 2016 shows that the proportion of highly engaged in work employees in China has increased to $10 \%$. Although some progresses have been made, it has not reached the global average of $13 \%$. It can be seen that Chinese employees still have a lot of room for improvement in their work inputs and it is imminent to find ways and means to enhance their work engagement.

No matter it is in academia or in business management practices, employee career growth has always been one of the focuses of great concern. In recent years, with more and more post-90s entering the workplace from campus and injecting fresh blood into the enterprise, this distinctively-featured group of new generation people is gradually becoming an important force for organization's sustainable development. The new generation employees at the present stage in China are more innovative and motivated by growth needs. They mainly emphasize their personal career growth. At the same time, they keep pursuing the satisfaction of personal needs and the achievement of career goals (Fok, 2016) [2]. Therefore, in the current employment situation, accumulating good professional values is indispensable for the group to obtain continuous professional competitiveness and achieve their own professional ideals. Thus, they are also paying more attention to the development of personal ability and career growth.

In recent years, scholars have begun to focus on the connection between career growth and employees' proactive behavior in enterprises. Okurame (2012) [3] has explored the relationship between career growth prospect and organizational citizenship behavior. Crawshaw et al. (2012) [4] have pointed out that it is necessary to study the relationship between employee career growth and work performance, work initiative behavior. In addition, Weng, Xi, Yuan, Zhou and other Chinese scholars have also pointed out that employee career growth has a significant impact on organizational commitment [5], employee engagement [6], turnover intention [7] [8] and work performance [9]. But so far, scholars rarely examine the relationship between career growth and work engagement, and there are few researches on the specific influence mechanism.

Therefore, this study is devoted to conducting in-depth research from the following two aspects: 1) To explain the relationship between career growth and work engagement among the new generation employees; 2) To explore the influence mechanism of career growth on work engagement, this study introduces organizational identification as an intermediary variable and introduces person-organization values fit as a regulatory variable. And then examine their influences on the main effect. 


\section{Literature Review and Research Hypothesis}

\subsection{Career Growth, Work Engagement and Organizational Identification}

Argyris (1957) [10] pointed out that career growth is the process of individual from passive dependence to active independence, from being unconstrained to being self-restrained. Graen (1997) [11] emphasized the benefits of occupational mobility between organizations to individual values increasing in his description of career growth, and defined career growth as the speed of work series that individuals pursuing value enhancement. Career growth was defined as the opportunity for individuals to gain career growth in an organization, such as undertaking challenging work tasks, taking on more job responsibilities and more. However, these concepts are not comprehensive enough and do not take the mobility problem of employees into account. Therefore, Chinese scholars Weng \& Hu (2009) [12] have suggested two ways of career growth: intra-organizational growth and inter-organizational growth. Intra-organizational Career growth emphasizes the speed of individual career progression within the organization. And inter-organizational career growth emphasizes the growth of experience and ability when individual flows between organizations. In addition, career growth was divided into three major dimensions: career goal progress, professional ability development and organizational remuneration growth (Weng et al., 2017) [5]. It is limited to career growth within the organization in this study.

With the rise of Positive Psychology and Positive Organizational Behavior, the concept of "work engagement" first appeared in 1965. After years of research and exploration by scholars, Kahn (1990) [13] put forward the concept of individual input at work basing on the study of Goffman (1966) [14], which was defined as that individuals within the organization could integrate into work and express themselves freely. It was also divided into three dimensions of physiological, Cognitive and emotional. Schaufeli et al. (2002) [15] considered that work engagement is a cognitive state which is more positive, more lasting and more universal. They also put forward the three-dimensional characterization factors of vitality, dedication and focus. This three-factor model has been universally accepted and adopted in academia.

For the concept of organizational identification, Ashforth \& Mael (1989) [16] introduced social identification theory into the organizational situations, recognizing that organizational identification is a state in which an individual defines himself or herself as a member of a particular organization, or a sense of belonging to the group. When employees feel they are respected, and then formed a dependence on the organization and a sense of belonging, they will be more willing to stay in the organization for a long time, contribute to the organization, enhance organizational performance and image etc.

\subsection{Career Growth and Work Engagement}

Work engagement is an active, integrated and persistent state of the individual in work [17]. To be specific, it can be manifested as whether employees have 
good psychological quality, lots of energy, and great enthusiasm in the work, can be absorbed in work and feel happy or not easy to produce listless, extreme and other negative behaviors. For the new generation employees, they grew up in an era of rich material life, developed market economy and rapid development of information technology. They are very concerned about personal career development and are eager to have more training opportunities to develop and perfect themselves.

According to the Theory of Need for Achievement, when enterprises establish a certain career growth space for new generation employees and give them sufficient opportunities to meet their growth needs and their desire for success to a certain degree. It will obviously enhance their vitality and dedication in work, so as to focus more devotion to work.

A large number of studies can show that career growth and work engagement are closely linked. Bakker (2008)'s study [18] of employees' psychological characteristics and work engagement found that individual psychological resources such as self-respect and optimism can effectively predict the degree of work engagement. The accumulation of professional values and the satisfaction of self needs which employees obtain in the organization will stimulate the individual to have a pleasant emotional experience. When the psychological resources of the individual are richer, their expectations for self-centeredness (self-employment and self-expression) are higher, but also have a higher sense of self-efficacy and subjective initiative. In addition to the impact of individual psychology, career growth also affects the impact of organizational members on work resources (such as perceived organizational support, environmental free perception, innovation support, organizational justice, matching perception) through increased capabilities, changing social and economic status and so on. Li (2006) [19] suggested that a high degree of fit between individual employees and organizations or jobs enables them to adapt quickly and get into work actively. The development opportunities (such as challenging assignment, skills utilization) which the organizations provide to employees for career management will promote the improvement of their work input and quality.

On the other hand, from the empirical research of Weng (2013) [5] \& Zhou (2015) [6], it can be concluded that in different occupational environment, the positive impact between career growth and organizational commitment is supported by empirical data. The factors related to organizational commitment also have a significant effect on work engagement. Li (2012)'s research [20] found that good psychosocial safety perception has a positive impact on work engagement. So employees' career growth can increase safety awareness of resource control and self-development, thus enhance their work input. Based on the above analysis, this paper proposes the following hypothesis:

H1: Employee career growth has a positive impact on work engagement.

\subsection{Career Growth and Organizational Identification}

Scholars generally believed that organizational identification is the affiliation 
and dependence of the members on the organization emotionally and psychologically. Employees will be tended to be actively consistent with organizations on both psychology and actions when they agree with the organizations' strategy, culture and values. Antecedents of organizational identification can be summarized into three categories: individual characteristics, organizational characteristics and environmental characteristics, of which organizational characteristics are mainly manifested as organizational image, organizational climate, organizational culture and organizational support etc. (Bao, 2006) [21]. If employees want to get more pay, improve their own professionalism and abilities, gain higher positions in work or social status, it is indispensable of the broad platform and challenge opportunities provided by organizations. In other words, in order to achieve their career growths, not only needed their own efforts, but also the support of the organization. The employee's intra-organizational career growth is not only the process of generating internal identification of the organization's goals, but also the gradually bundling of the self-behavior and organizational development [5].

The study of Zhou \& Yu (2015) found that employee career growth has a significant positive effect on organizational commitment [6]. That's to say, when employees feel that they are respected enough in the organization, be able to improve their self-worth and achieve their career goals better, they will be more recognized to the organization and more willing to stay in the organization by working harder toward their goals. At the same time, they will give more return to the organization, bringing better benefits to the organization thereby. Based on the above analysis, this paper proposes the following hypothesis:

H2: The career growth of employees has a positive impact on organizational identification.

\subsection{Organizational Identification and Work Engagement}

According to the Theory of Social Identity, an individual can effectively perceive himself in a particular social group or organization, and can recognize the emotional affiliation and value enhancement obtained after belonging to this particular group or organization. As a member of the organization, when it has a sense of belonging and emotional dependence on the organization, it will consider for the organization Initiatively, weigh it's decision-making, and try to help organizations to achieve maximum benefits. Sometimes, employee would like to devote more time, energy and extra efforts to achieve the interests of the organization.

Regarding the relationship between organizational identification and work engagement, some scholars have found that there is a positive relationship between them. He \& Ling (2008) [22] concluded that emotional identification has a very significant positive impact on all three dimensions of employee's work engagement, and the evaluation of the identity can significantly affect the vitality dimension. Moreover, a large number of studies showed that organizational identification will have a significant positive impact on organizational commit- 
ment, employee suggestion behavior and organizational citizenship. Therefore, this study infers that organizational identification may help to enhance the sense of responsibility and mission of employees so as to devote more efforts to their jobs, and even consciously undertake work without their responsibilities. Based on the above analysis, this paper proposes the following hypothesis:

H3: Organizational identification has a positive impact on employee's work engagement.

\subsection{The Intermediary Role of Organizational Identification}

The career growth perceived by employee influence staff's psychological cognitive evaluation is mainly through the consistency of practical work and career direction, abundant work experience related to career ideal, skills upgrading, the growth of social capital in the organization and the material return by the organization due to its work engagement, thereby affecting their attitudes and behavior. Reciprocity between individuals and organizations is reflected in the equivalent exchange of resources (including material, immaterial and psychological resources). And in the process of exchange relations running-in until balance, the high degree of recognition for career growth that individuals obtain within the organization is the center of gravity of this balance.

Therefore, if organizations want employees to have a higher level of work engagement in their work environment, they need to provide employees with adequate career development support. So that they can not only feeling high degree of concern and recognition from the organization, but also gain their accumulation of professional value. Thus, employee would form a stronger sense of belonging to the organization, consciously raise their willingness to continue their dedication, increase their enthusiasm for work, create greater work output, and increase the profitability of the organization. Consequently, this paper argues that the reason why career growth can increase employee's work engagement is the important role of organizational identification. Based on the above analysis, this paper proposes the following hypothesis:

H4: Organizational identification has mediating effect between career growth and work engagement.

\subsection{The Moderating Effect of Person-Organization Value Fit}

Person-organization value fit is one of the person-organization fit. Kristof (1996) [23], a well-known scholar who is researching fit theory, summarized person-organization value fit as a kind of assisted fit, emphasized the similarity or consistency of the characteristics between individuals and organizations, and promoted individuals' performance by enhancing individual-organization compatibility. Employees that are more aligned with the organization or group will make the organization more efficient and improve the organization's competitive advantage. Values can be defined as a particular preference of behavior for individual or society. Personal value is a unique personal ideas and habits etc. 
formed in a certain environment. Organizational value is the behavioral pattern advocated by the organization in the constant pursuit of sustainable development. It affects the individual's mind and behavior and become the core source of power for the organization. Person-organization value fit refers to the values of individuals and organizations where the values are similar or compatible [24].

Above the definition of person-organization value fit, if the values of individuals and organizations are more consistent, individuals are more likely to have a strong sense of teamwork and belonging, and more inclined to treat themselves as really members of the organization. And organizational identification can be seen as a self-definition which is the result of comparing an individual's own values with the organization. Ashforth (1989) \& Tajfel (2004) [16] argued that among the various factors that influence organizational identification, the values are most valued by them. The idea also supports the view of this study.

This study argues that while career growth does not have a direct effect on the person-organization value fit, but in the situation of the high level of consistency between the values of individuals and the values of their organizations, new generation employees may gain greater organizational recognition if they are given the opportunities to receive career guidance, training, promotion and salary increase. On the contrary, if the level of person-organization value fit is low, the impact of career growth on organizational identification is weak. Therefore, this study proposes the following hypothesis:

H5: Person-organization value fit plays a positive regulatory role in the impact of career growth on organizational identification.

In summary, we discussed the influence mechanism of career growth on work engagement, and introduced organizational identification as a mediator variable, person-organization value fit as a regulatory variable. Based on this, five hypotheses were proposed. And the theoretical model of this study is shown in Figure 1.

\section{Research Methods}

\subsection{Data Collection and Samples}

In this study, the data were collected by questionnaire. The survey mainly covered 6 companies in the Pearl River Delta region, involving finance, Internet, real estate, management consulting and other industries. Such as Gemdale, Tencent, Yuexiu Group, KPMG, CGB and TP-LINK. Since the research object of this study was new generation employees, a total of 250 questionnaires were issued to employees in the enterprise with working years of 0 to 6 . After validating the incomplete and other invalid questionnaires, the number of valid questionnaires was 207 and the effective rate reached $82.8 \%$.

Among the effective samples, 95 people were males (45.9\%) and 112 people were females $(54.1 \%)$, it was basically balanced in sex ratio. In academic distribution, mainly included undergraduate, master's degree or above, employees of undergraduate education accounted for $63.8 \%$, employees of master's degree or 


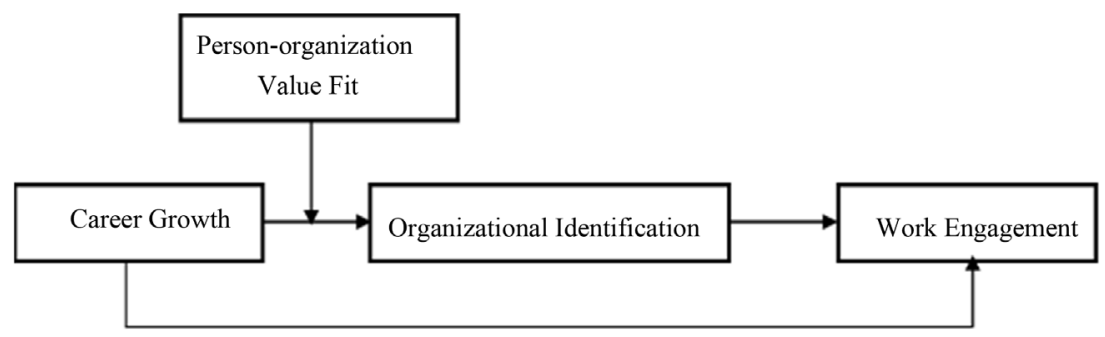

Figure 1. The relationship model of career growth, work engagement, organizational identification and person-organization value fit.

above accounted for 29.5\%. Employees' working years were mainly 1 - 3 years (85.5\%), basically meeting the characteristics and requirements of new generation employees.

\subsection{Variable Measurement}

The scales of the selected variables in this study were all from the mature scale of the existing studies. The scales used in this study are all Likert 5 points scale, in which " 1 " means "totally disagree" and " 5 " means "totally agree". In order to ensure the accuracy and situational applicability of the scale, after the preliminary survey, we conducted in-depth interviews and corrections with some professional technicians and relevant scholars on the contents of the questionnaire, form the final scale and conducted the formal survey of the second stage. The scales are as follows:

Career Growth: Using the Career Growth scale revised by Weng and McElory (2012), which has 15 items in total and is divided into three dimensions: career goal progress, professional ability development and organizational remuneration growth. For example, the item of career goal progress "the current job is one step closer to my career goal" and the item of professional ability development "the current job motivates me to continuously acquire new knowledge about work" and so on. According to the data of valid samples in this study, the Cronbach's $\alpha$ of this scale was 0.901 , and the reliability was good.

Organizational Identification: Using the scale developed by Mael et al. [25], in which there are 6 items in total. This scale has been widely used in the current researches of organizational identification. For example: "I am concerned about others' evaluation of my work unit very much." In this study, the Cronbach's $\alpha$ was 0.81 .

Work Engagement: Using the Utrecht Work Engagement Scale by Schaufeli and Bakke (2003) [26], which consists of three dimensions of vigor, dedication and absorption, including 17 items such as "I feel energetic at work" and "I am passionate about what I am doing". There are 6 items in the vigor dimension, 5 items in the dedication dimension and 6 items in the absorption dimension. In this study, the Cronbach's $\alpha$ was 0.943 .

Person-organization Value Fit: Considering the scalability and simplicity of the scale, this study used a direct measurement method and selected the value fit 
dimensions from the person-organization fit scale which was compiled by Resick et al. (2007) [27] as the scale of this study. The scale has 5 items in total, including "My values are in line with the values of the units and the surrounding environment" and so on. In this study, the Cronbach's $\alpha$ was 0.823 .

Control variables: Selecting gender, degree of education, years of working, nature of unit as control variables.

\section{Data Analysis and Research Result}

\subsection{Confirmatory Factor Analysis}

Since the data in this study were from questionnaires filled in by employees, it can easily lead to common method variance. This study used AMOS 21.0 to conduct confirmatory factor analysis, testing the discriminant validity of the predictor variables in different models. Table 1 shows the results.

Six fitting indicators were adopted in this study: $\chi^{2} / \mathrm{df}$, RMSEA, IFI, TLI, CFI and AIC. For these indicators, the standards generally accepted by academics are: when $\chi^{2} / \mathrm{df}$ is between 1 and 3 , the model fitting degree is better, the smaller, the more ideal; when RMSEA is less than 0.05, the model fitting degree is ideal; IFI, TLI, CFI and other indicators are generally between 0 and 1 , the closer to 1 , the better the model fits. Most scholars believe that when the indicators are higher than 0.9, the model achieves a good fit.

By comparing the six models in Table 1, it was found that the four-factor model had the best fit $\left(\chi^{2} / \mathrm{df}=1.386\right.$; RMSEA $=0.043$, less than 0.05 ; all three indexes of IFI, TLI and CFI are higher than 0.9). Therefore, the analysis results showed that there is no serious common method variance between the variables, and the predictor variables have good discriminant validity.

\subsection{Correlation Analysis}

The mean, standard deviation and the correlation coefficients between every control variable, career growth, organizational identification, work engagement and person-organization value fit are shown in Table 2. The results show that there is a significant positive correlation between new generation employees' career growth and organizational identification $(r=0.653, p<0.01)$ and work engagement $(r=0.308, p<0.01)$, and that there is also a significant positive correlation between organizational identification and work engagement $(r=0.360, p$ $<0.01$ ). These provide preliminary support for testing the hypothesis of this study. In addition, we will control gender, degree of education, years of working and nature of unit in the regression analysis.

\subsection{Hypothesis Text}

This study mainly used multiple regression methods and Bootstrap method to examine the relationship between variables. Before analyzing the data, in order to avoid multicollinearity problem, each variable was centralized. Table 3 shows the results of multiple regression analysis. 
Table 1. The result of confirmatory factor analysis $(\mathrm{N}=207)$.

\begin{tabular}{ccccccccc}
\hline Model & \multicolumn{1}{c}{$\chi^{2}$} & $\mathrm{df}$ & $\chi^{2} / \mathrm{df}$ & RMSEA & IFI & TLI & CFI & AIC \\
\hline 4-factor model & 1146.071 & 827 & 1.386 & 0.043 & 0.936 & 0.929 & 0.935 & 1384.071 \\
3-factor model A & 1615.576 & 832 & 1.942 & 0.068 & 0.842 & 0.826 & 0.840 & 1843.576 \\
3-factor model B & 1454.723 & 838 & 1.736 & 0.060 & 0.875 & 0.864 & 0.874 & 1670.723 \\
3-factor model C & 1522.897 & 846 & 1.800 & 0.062 & 0.863 & 0.852 & 0.861 & 1722.897 \\
2-factor model & 1955.317 & 842 & 2.322 & 0.080 & 0.775 & 0.756 & 0.772 & 2163.317 \\
1-factor model & 2309.626 & 845 & 2.733 & 0.092 & 0.704 & 0.680 & 0.700 & 2511.626 \\
\hline
\end{tabular}

Annotation: model A combines Career Growth and Work Engagement; model B combines Organizational Identification and Work Engagement; model C combines Organizational Identification and Person-organization Value Fit; 2-factors model combines Career Growth and Work Engagement, Organizational Identification and Person-organization Value Fit.

Table 2. The means, standard deviation and the correlation coefficients.

\begin{tabular}{ccccccccccc}
\hline Variable & Mean & SD & $\mathbf{1}$ & $\mathbf{2}$ & $\mathbf{3}$ & $\mathbf{4}$ & $\mathbf{5}$ & $\mathbf{6}$ & $\mathbf{7}$ & $\mathbf{8}$ \\
\hline 1 Gender & 1.54 & 0.5 & 1 & & & & & & & \\
2 Education & 3.18 & 0.691 & 0.014 & 1 & & & & & & \\
3 YOF & 1.89 & 0.989 & -0.021 & $-0.292^{* *}$ & 1 & & & & & \\
4 NOU & 2.79 & 1.103 & -0.002 & $-0.294^{* *}$ & $0.139^{*}$ & 1 & & & & \\
5 CG & 3.50 & 0.535 & 0.049 & -0.005 & 0.007 & -0.015 & 1 & & & \\
6 POVF & 3.48 & 0.596 & 0.044 & -0.003 & 0.028 & $-0.162^{*}$ & $0.556^{* *}$ & 1 & & \\
7 OI & 3.40 & 0.589 & 0.047 & -0.042 & 0.059 & -0.104 & $0.615^{* *}$ & $0.646^{* *}$ & 1 & \\
8 WE & 3.54 & 0.598 & 0.017 & -0.11 & -0.011 & -0.116 & $0.308^{* *}$ & $0.380^{* *} 0.343^{* *}$ & 1 \\
\hline
\end{tabular}

Annotation: $\mathrm{n}=207 ;{ }^{*} \mathrm{p}<0.05 ;{ }^{*} \mathrm{p}<0.01$; YOF represents years of working, NOU represents nature of unit, CG represents career growth, POVF represents person-organization value fit, OI represents organizational identification, WE represents work engagement.

1) From the model 5 in Table 3 , it can be seen that career growth has a significant positive effect on work engagement $(\beta=0.342, \mathrm{p}<0.01)$. That is the faster career growth, the higher the employee's work commitment. So Hypothesis 1 is supported.

2) As shown in model 2 and model 6 , career growth has a significant positive effect on organizational identification $(\beta=0.674, \mathrm{p}<0.01)$ and organizational identification also has a significant positive effect on work engagement $(\beta=$ $0.336, \mathrm{p}<0.01$ ). Therefore, Hypothesis 2 and Hypothesis 3 are supported. At the same time, it also satisfies the preconditions for testing the mediating effect of organizational identification.

3) The test of mediating effect. Firstly, intermediary effect test method summarized by Wen (2004) [28] was used in this study. From the results of 1) and 2 ), we can see that the significant regression relationship between career growth and organizational identification \& work commitment. After joining organizational identification in the process, the regression coefficient of career growth to 
Table 3. The result of multiple regression.

\begin{tabular}{|c|c|c|c|c|c|c|}
\hline \multirow{2}{*}{ Variable } & \multicolumn{3}{|c|}{ Organizational Identification } & \multicolumn{3}{|c|}{ Work Engagement } \\
\hline & Modle 1 & Modle 2 & Modle 3 & Modle 4 & Modle 5 & Modle 6 \\
\hline Constant & $3.520^{\star *}$ & $1.195^{\star *}$ & $0.307^{\star}$ & $4.286^{* *}$ & $3.108^{* *}$ & $3.103^{* *}$ \\
\hline Gender & 0.059 & 0.024 & 0.021 & 0.021 & 0.003 & 0.001 \\
\hline Education & -0.048 & -0.044 & -0.019 & $-0.148^{*}$ & $-0.146^{*}$ & $-0.132^{*}$ \\
\hline Years of Working & 0.015 & 0.014 & 0.009 & -0.016 & -0.017 & -0.021 \\
\hline Nature of Unit & -0.073 & $-0.066^{*}$ & -0.024 & -0.086 & $-0.083^{*}$ & -0.062 \\
\hline Career Growth & & $0.674^{\star *}$ & $0.430^{\star *}$ & & $0.342^{\star \star}$ & \\
\hline OI & & & & & & $0.336^{\star *}$ \\
\hline POVF & & & $0.443^{* *}$ & & & \\
\hline $\mathrm{CG} \times \mathrm{POVF}$ & & & $0.179^{* *}$ & & & \\
\hline F & 1.105 & $22.188^{* *}$ & $27.819^{* *}$ & 1.608 & $5.051^{\star *}$ & $5.666^{* *}$ \\
\hline $\mathbf{R}^{2}$ & 0.027 & 0.400 & 0.529 & 0.038 & 0.132 & 0.145 \\
\hline$\Delta \mathrm{R}^{2}$ & & $0.382^{* *}$ & $0.510^{* *}$ & & $0.106^{\star *}$ & $0.120^{* *}$ \\
\hline
\end{tabular}

Annotation: $\mathrm{n}=207 ;{ }^{*} \mathrm{p}<0.05 ;{ }^{* *} \mathrm{p}<0.01$; YOF represents years of working, NOU represents nature of unit, CG represents career growth, POVF represents person-organization value fit, OI represents organizational identification, WE represents work engagement.

work engagement is still significant, but the coefficient value becomes smaller. This preliminarily demonstrates that the organizational identification plays a mediating role in the relationship between career growth and work engagement. However, many scholars thought that this method had some limitations. To further ensure the rigor of this study, we further examine the mediation effect by using the Bootstrap method of Hayes (2013) [20]. We choose 5000 as sample size. Under 95\% confidence interval, the results of the intermediate test did not contain $0($ LLCT $=0.063$, ULCI $=0.399)$, which indicates that the mediating effect of organizational identification is significant, and the mediating effect size is 0.230 . At the same time, the influence of career growth on employee's work engagement is still significant after controlling the intermediary variables (LLCT $=$ 0.195 , ULCI $=0.506, \mathrm{p}<0.01)$. Therefore, organization identification plays a partial mediating role between career growth and work engagement. Hypothesis 4 is supported.

4) Examining the regulatory role of person-organization value fit between career growth and organizational identification. As shown in Model 3, the interaction between career growth and person-organization value fit has a significant effect on organizational identification $(\beta=0.179, \mathrm{p}<0.01)$. Similarly, in order to further examine the regulatory effect, this study used the Bootstrap method, selected the sample size of 5000 and the confidence interval whose coefficient is $95 \%$. The result showed that the influence of career growth on organizational identification is significantly regulated by person-organization value fit (LLCT = 0.032 , ULCI $=0.432$ ). Therefore, Hypothesis 5 is supported. 


\section{Research Findings and Conclusions}

\subsection{Research Findings}

Based on Social Exchange Theory, Matching Theory and Positive Psychology, this study explored the impact of intra-organizational career growth on employee's work engagement aimed at the specific group of new generation employees, and introduced two variables of organizational identification and person-organization value fit for further study. According to the analysis of empirical data, this study draws the following findings.

First of all, the career growth of new generation employees has a significant positive effect on organizational identification and work engagement. This conclusion shows that if employees perceive that they can achieve better career growth in the organization, they will be more attracted to the organization and form a strong sense of belonging and responsibility towards the organization. In addition, they will invest more enthusiasm and energy in their work. While improving the performance for their organization, they will continue to develop new job skills, enhance their professional abilities and accomplishments, so as to near their professional goals.

And then this study found that organizational identification plays a partial mediating role between career growth and work engagement. In other words, the career growth which the new generation employees obtain in the organization can not only directly affect their actual work engagement, but also indirectly enhance their work engagement by enhancing the emotional connection between employees and organizations.

Finally, we confirmed that person-organization value fit plays a positive regulatory role in the relationship between career growth and organizational identification. In other words, the impact of career growth on organizational identification will be significantly enhanced when the level of person-organization value fit is high. On the contrary, the impact of career growth on organizational identification will be weakened when the level of person-organization value fit is low. Therefore, for this study, unilaterally emphasis on the career growth of new generation employees while neglecting employee-organization value fit can't maximize employees' recognition of the organization. Only when the two are combined, can the best incentive effect be achieved.

\subsection{Research Conclusions}

Starting from practical problems, this study selects new generation employees as research object to explore the relationship between career growth and work engagement. Through the analysis of empirical data, the hypothesis has been supported. This paper has important significance whether in theoretical development or enterprise practice. Next the theoretical contributions and management implications will be discussed.

\subsubsection{Theoretical Contributions}

The theoretical contributions of this study mainly include the following three 
aspects:

Firstly, for the new generation employee groups, it was concluded that the career growth of employees has a significant positive impact on their work engagement through the data test. This is similar to the conclusions of Li (2012) [20] and Weng (2017) [9], further demonstrating the importance of paying attention to employee career development and career growth.

Secondly, while the positive relationship between career growth and work engagement was confirmed, there was almost no explanation of how career growth affects work engagement. This study introduced organizational identification as an intermediary variable and obtained the support from the data. It concluded that organizational identification does play an intermediary role in the process of career growth affecting work engagement. If organizations invest more resources (such as high-value work items, valuable training opportunities, promotion opportunities etc.) for employees, they will pay more attention to the psychological contract with the organization and really consider themselves as a member of the organization. In exchange, they will get into work in a better state to work to return the organization. Therefore, this study further uncovered the internal mechanism of career growth impacting work engagement, laying a good theoretical foundation for scholars to further study this process and enriching the theoretical connotation of career growth and work engagement.

Finally, this study also explored the regulatory role of person-organization value fit in the relationship between career growth and organizational identification. It demonstrated that in the case of high person-organization value fit, giving employees better career growth opportunities can achieve better incentive effects on employees. Edwards and Cable (2009) [29] argued that consistency of values means that it is similar to the values held by individuals and organizations. If employees' values are in line with the organization's values, they are more likely to recognize the organization's cultural atmosphere, strategic decisions and so on, then accept and like their organizations from the bottom of their heart. On the contrary, if employees' values conflict with the organization's, employees will possibly have negative emotions that are conflicting or even resistance to the organization, and thus being in a bad state of work burnout, which is detrimental to the output of organizational performance. This conclusion also promotes the development of the theory of job matching to a certain extent.

However, there are still some limitations in this study. For example, the generality of the sample is not enough due to the geographical restrictions. Otherwise, the common method deviation was caused by the cross-sectional measurement.

\subsubsection{Management Implications}

Under the background of increasingly fierce market competition, the new generation employees as an important force for the organizational sustainable development are getting more and more attention by business managers and scho- 
lars. How to make these young people more involved into their work is an urgent problem to be resolved. Based on the conclusions drawn from this study, the following suggestions are proposed in terms of career growth, organizational identification, value fit and so on:

Firstly, organizations need to fully understand the career growth needs of new generation employees. The organizations should have an in-depth understanding of their employees' career goals and help them plan their careers rationally. For different types of employees, the organizations should provide different challenging job opportunities and professional ability trainings so that employees can be fully exercised and promoted. At the same time, a good job promotion path and reasonable remuneration growth are indispensable because it is an affirmation of employees' self-achievement and value.

Secondly, organizations should focus on improving employees' recognition of themselves. Employees with high organization identification tend to regarded themselves as representatives of the organizations, are who can easy to generate organizational citizenship behavior and cooperative attitudes, and have high satisfaction and low turnover intentions. Therefore, the organizations can enhance their positive specificity and enrich the life of employees by advocating unique corporate culture and values, designing novel workflows, actively organizing corporate collective activities and so on. In this way, employees' emotional attribution and dependence on the organizations are enhanced to form an identification on the organizations, which in turn increases their work engagement.

Finally, organizations should pay attention to the study of talent adaptation. According to Expectancy Theory, satisfaction comes from the cognition of the gap between expectation and reality. In real situations, the high short-term turnover rate of new generation employees often comes from the mismatch between actual work and career expectations. Therefore, at the stage of talent selection and recruitment, the recruiters also need to carefully examine the candidate's own career expectations and values, and conduct matching and testing based on the actual conditions of the organizations. So that can improve the quality of two-way choice between individuals and organizations and the level of commitment.

\section{References}

[1] Grillo, G. (2013) Gallup Global Employee Engagement Survey Report. http://www.guancha.cn/america/2013_11_08_184201.shtml

[2] Fok, R.H.M. and Yeung, R.M.W. (2016) Work Attitudes of Generation Y in Macau's Hotel Industry: Management's Perspective. Worldwide Hospitality \& Tourism Themes, 8, 83-96. https://doi.org/10.1108/WHATT-10-2015-0034

[3] Okurame, D. (2012) Impact of Career Growth Prospects and Formal Mentoring on Organizational Citizenship Behavior. Leadership \& Organization Development Journal, 33, 66-85. https://doi.org/10.1108/01437731211193124

[4] Crawshaw, J.R., Dick, R.V. and Brodbeck, F.C. (2012) Opportunity, Fair Process and Relationship Value: Career Development as a Driver of Proactive Work Behavior. Human Resource Management Journal, 22, 4-20. 
https://doi.org/10.1111/j.1748-8583.2011.00169.x

[5] Weng, Q.X. and Xi, Y.M. (2013) The Relationship between Career Growth, Organizational Commitment and Turnover Intention: A Comparison between Industrial Clusters and Non-Clusters. Forecasting, 32, 23-30. https://espace.library.uq.edu.au/view/UQ:326871

[6] Zhou, X., Yu, J.M. and Cao, G.L. (2015) The Impact of Career Growth on Employee Engagement-Based on the Mediating Role of Organizational Commitment. Soft Science, 29, 88-91.

http://en.cnki.com.cn/Article_en/CJFDTotal-XUXI201510019.htm

[7] Weng, Q.X. and Xi, Y.M. (2010) The Impact Mechanism of Career Growth on Turnover Intention: The Mediated Role of Career Commitment and Perceived Opportunities. Nankai Business Review, 13, 119-131.

http://en.cnki.com.cn/Article_en/CJFDTotal-LKGP201002015.htm

[8] Yuan, Q.H., Ding, G. and Li, H. (2014) The Impact of Career Growth on Turnover Intention for Knowledge Worker: The Moderating Role of Organizational Identification and Professional Identification. Science of Science and Management of S.\& T., 35, 155-164. http://en.cnki.com.cn/Article_en/CJFDTotal-KXXG201401020.htm

[9] Weng, Q.X., Yang, H. and Cao, X.X. (2017) Relationship of Researcher's Career Growth and Work Engagement with Job Performance. Science Research Management, 38, 144-151.

http://en.cnki.com.cn/Article_en/CJFDTotal-KYGL201706017.htm

[10] Argyris, C. (1957) Personality and Organization: the Conflict between System and the Individual. Harper \& Row, New York.

[11] Graen, G.B., Chun, H., Dharwadkar, R., Grewal, R. and Wakabayashi, M. (1997) Predicting Speed of Managerial Advancement over 23 Years Using a Parametric Duration Analysis: A Test of Early Leader-Member Exchange, Early Job Performance, Early Career Success, and University Prestige. Best Papers Proceedings: Making Global Partnerships Work. Association of Japanese Business Studies, Washington DC.

[12] Weng, Q.X. and Hu, B. (2009) The Structure of Career Growth and Its Impact on Employees' Turnover Intention. Industrial Engineering and Management, 14. 97-104. http://en.cnki.com.cn/Article_en/CJFDTOTAL-GYGC200901023.htm

[13] Kahn, W.A. (1990) Psychological Conditions of Personal Engagement and Disengagement at Work. Academy of Management Journal, 33, 692-724. https://doi.org/10.2307/256287

[14] Kahn W.A. (1992) To Be Fully There: Psychological Presence at Work. Human Relations, 45, 321-349. https://doi.org/10.1177/001872679204500402

[15] Schaufeli, W.B., Salanova, M., González-Romá, V. and Bakker, A.B. (2002) The Measurement of Engagement and Burnout: A Two Sample Confirmatory Factor Analytic Approach. Journal of Happiness Studies, 3, 71-92. https://doi.org/10.1023/A:1015630930326

[16] Ashforth, B.E. and Mael, F. (1989) Social Identity Theory and the Organization. Academy of Management Review, 14, 20-39.

[17] Hu, S.N. and Wang, Y. (2014) Concept, Measurements, Antecedents and Consequences of Work Engagement. Advances in Psychological Science, 22, 1975-1984. http://journal.psych.ac.cn/xlkxjz/EN/Y2014/V22/I12/1975 https://doi.org/10.3724/SP.J.1042.2014.01975

[18] Bakker, A.B., Demerouti, E. and Brummelhuis, L.L. (2012) Work Engagement, Per- 
formance, and Active Learning: The Role of Conscientiousness. Journal of Vocational Behavior, 80, 555-564. https://doi.org/10.1016/j.jvb.2011.08.008

[19] Li, J.B., Xu, B.H. and Chen, J.M. (2006) The Effect of Organizational Factors on Job Engagement. Chinese Journal of Applied Psychology, 12, 176-181. http://en.cnki.com.cn/Article_en/CJFDTotal-YXNX200602011.htm

[20] Li, Y. (2012) A Research about the Mechanism of Supervisor-Subordinated "Guanxi” Influencing Career Growth and Work Engagement about the Middle Managers. PhD Thesis, Wuhan University, Wuhan.

[21] Bao, G.M. and Xu, B.X. (2006) A Review of Organizational Identity Theory. Foreign Economics \& Management, 28, 39-45.

[22] He, L. and Ling, W.Q. (2008) An Empirical Study on Interaction among Different Organizational Culture, Organizational Identification and Job Engagement. Science of Science and Management of S. \& T., 325, 139-143. http://en.cnki.com.cn/Article_en/CJFDTotal-KXXG200810028.htm

[23] Kristof, A.L. (1996) Person-Organization Fit: An Integrative Review of Its Conceptualizations, Measurement, and Implications. Personnel Psychology, 49, 1-49. https://doi.org/10.1111/j.1744-6570.1996.tb01790.x

[24] Hoffman, B.J., Bynum, B.H., Piccolo, R.F. and Sutton, A.W. (2011) Person-Organization Value Congruence: How Transformational Leaders Influence Work Group Effectiveness. Academy of Management Journal, 54, 779-796. https://doi.org/10.5465/AMJ.2011.64870139

[25] Mael, F. and Ashforth, B.E. (1992) Alumni and Their Alma Mater: A Partial Test of the Reformulated Model of Organizational Identification. Journal of Organizational Behavior, 13, 103-123. https://doi.org/10.1002/job.4030130202

[26] Schaufeli, W.B. and Bakker, A.B. (2003) UWES-Utrecht Work Engagement Scale: Test Manual. Unpublished Manuscript, Department of Psychology, Utrecht University, Utrecht.

[27] Resick, C.J., Baltes, B.B. and Shantz, C.W. (2007) Person-Organization Fit and Work-Related Attitudes and Decisions: Examining Interactive Effects with Job Fit and Conscientiousness. Journal of Applied Psychology, 92, 1446-1455. https://doi.org/10.1037/0021-9010.92.5.1446

[28] Wen, Z.L., Zhang, L., Hou, J.T. and Liu, H.Y. (2004) Testing and Application of the Mediating Effects. Acta Psychologica Sinica, 36, 614-620. http://journal.psych.ac.cn/xlxb/CN/Y2004/V36/I05/614

[29] Edwards, J.R. and Cable, D.M. (2009) The Value of Value Congruence. Journal of Applied Psychology, 94, 654-677. https://doi.org/10.1037/a0014891 


\section{Appendix}

The Questionnaire about the Influence of Career Growth on Work Engagement Dear Sir/Madam:

Hello! I'm a master student from South China University of Technology, Institute of Business Administration. First of all, thank you for taking the time to read and fill out the questionnaire. Your participation and support will contribute to the smooth progress of this study. Please fill in the questionnaire according to your actual feelings and opinions. There is no right or wrong answer.

This questionnaire is filled with anonymous form, it does not involve personal privacy and trade secrets. And the survey data is only used for academic research.

Finally, I sincerely hope that you can truthfully fill in it.

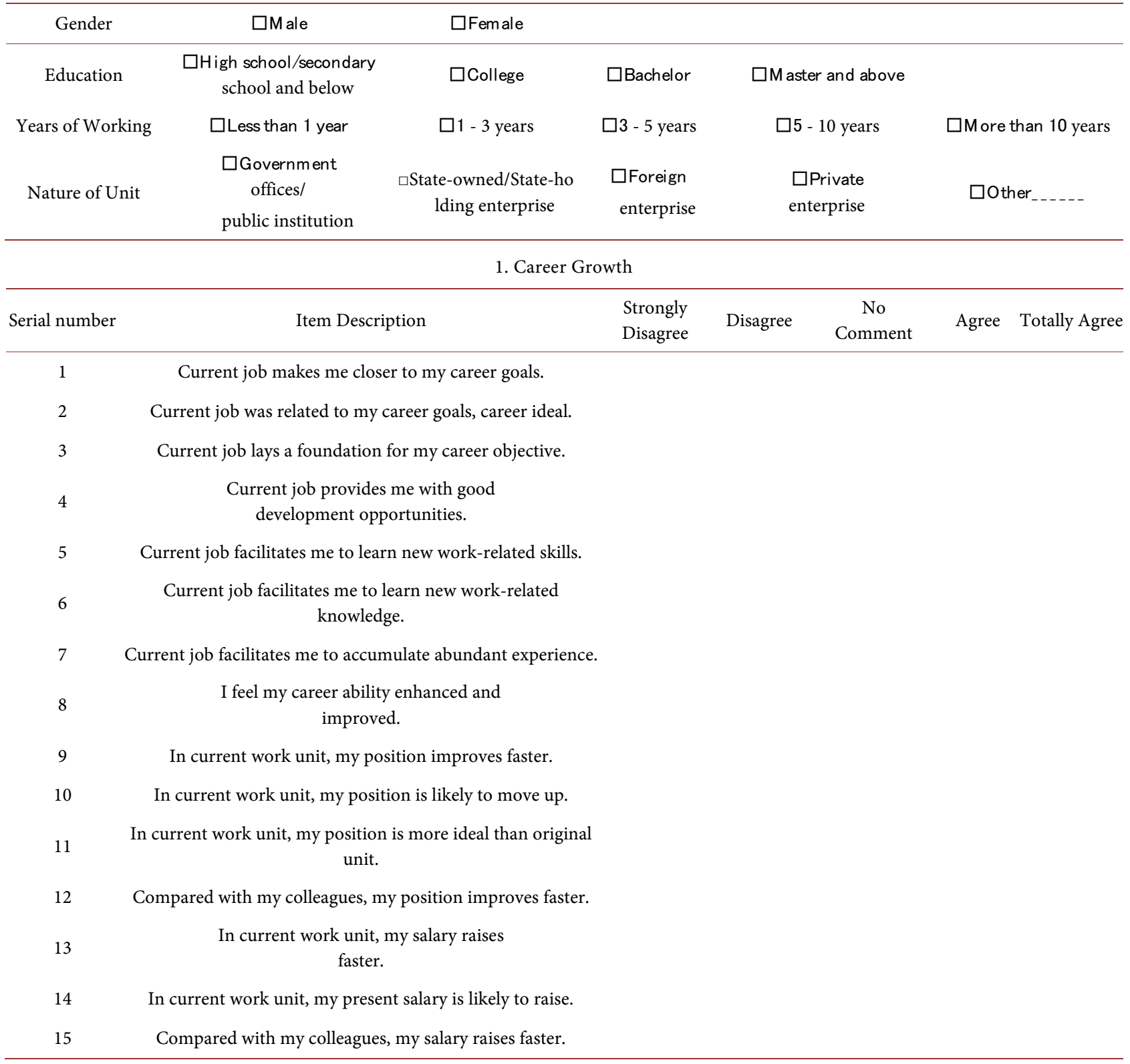


2. Organizational Identification

\begin{tabular}{|c|c|c|c|c|c|c|}
\hline $\begin{array}{c}\text { Serial } \\
\text { number }\end{array}$ & & $\begin{array}{l}\text { Strongly } \\
\text { Disagree }\end{array}$ & Disagree & $\begin{array}{c}\text { No } \\
\text { Comment }\end{array}$ & Agree & $\begin{array}{c}\text { Totally } \\
\text { Agree }\end{array}$ \\
\hline 1 & When someone blames my unit, I feel like blaming myself. & & & & & \\
\hline 2 & I am very concerned about the evaluation of my work unit. & & & & & \\
\hline 3 & I often use "we" not "they" to describe my unit instead & & & & & \\
\hline 4 & I think the development of the unit is my personal development. & & & & & \\
\hline 5 & When someone praises my unit, I feel like praising myself. & & & & & \\
\hline 6 & $\begin{array}{l}\text { If my unit is criticized by the media for something, I will feel very } \\
\text { uncomfortable. }\end{array}$ & & & & & \\
\hline
\end{tabular}

\begin{tabular}{|c|c|c|c|c|c|c|}
\hline \multicolumn{7}{|c|}{ 3. Work Engagement } \\
\hline $\begin{array}{c}\text { Serial } \\
\text { number }\end{array}$ & & $\begin{array}{l}\text { Strongly } \\
\text { Disagree }\end{array}$ & Disagree & $\begin{array}{c}\text { No } \\
\text { Comment }\end{array}$ & Agree & $\begin{array}{l}\text { Totally } \\
\text { Agree }\end{array}$ \\
\hline 1 & When I get up in the morning, I feel like going to work. & & & & & \\
\hline 2 & At my work, I feel bursting with energy. & & & & & \\
\hline 3 & At my work, I always persevere, even when things do not go well. & & & & & \\
\hline 4 & At my job, I feel strong and vigorous. & & & & & \\
\hline 5 & At my job, I am very resilient, mentally. & & & & & \\
\hline 6 & I can continue working for very long periods at a time. & & & & & \\
\hline 7 & I am proud of the work that I do. & & & & & \\
\hline 8 & I find the work that I do full of meaning and purpose. & & & & & \\
\hline 9 & My job inspires me. & & & & & \\
\hline 10 & I am enthusiastic about my job. & & & & & \\
\hline 11 & To me, my job is challenging. & & & & & \\
\hline 12 & I get carried away when I am working. & & & & & \\
\hline 13 & Time flies when I am working. & & & & & \\
\hline 14 & When I am working, I forget everything else around me. & & & & & \\
\hline 15 & I feel happy when I am working intensely. & & & & & \\
\hline 16 & I am immersed in my work. & & & & & \\
\hline 17 & It is difficult to detach myself from my job. & & & & & \\
\hline \multicolumn{7}{|c|}{ 4. Person-organization Value Fit } \\
\hline $\begin{array}{c}\text { Serial } \\
\text { number }\end{array}$ & & $\begin{array}{l}\text { Strongly } \\
\text { Disagree }\end{array}$ & Disagree & $\begin{array}{l}\text { No } \\
\text { Comment }\end{array}$ & Agree & $\begin{array}{l}\text { Totally } \\
\text { Agree }\end{array}$ \\
\hline 1 & My values match the values of the unit. & & & & & \\
\hline 2 & $\begin{array}{l}\text { The unit's values and personality can reflect my values and } \\
\text { personality. }\end{array}$ & & & & & \\
\hline 3 & My values are consistent with those of other colleagues in the unit. & & & & & \\
\hline 4 & $\begin{array}{l}\text { My personality characteristics match the } \\
\text { "personality" or image of the unit. }\end{array}$ & & & & & \\
\hline 5 & $\begin{array}{c}\text { My values fit in with the values of the unit and the surrounding } \\
\text { environment }\end{array}$ & & & & & \\
\hline
\end{tabular}

